\title{
Trophic relationships of a subtidal fish assemblage in the Francisco Coloane Coastal Marine Protected Area, southern Chilean Patagonia
}

\author{
Mathias Hüne ${ }^{a}$, Ernesto Davis ${ }^{b}$, Silvia Murciac ${ }^{c}$ David Gutiérrez ${ }^{d}$ \& Daniela Haro ${ }^{e}$ \\ aFundación Ictiológica, Santiago, Chile; ${ }^{\text {bC}}$ entro de Estudios del Cuaternario de Fuego-Patagonia y Antártica, Punta Arenas, Chile; \\ 'Laboratorio de Ecosistemas Marinos Antárticos y Subantárticos, Universidad de Magallanes, Punta Arenas, Chile; 'Fundación para la \\ Integración del Patrimonio Natural y Cultural, Santiago, Chile; 'Laboratorio de Ecofisiología y Ecología Isotópica, Universidad de Chile, \\ Santiago, Chile
}

\begin{abstract}
A combination of stomach content and nitrogen $\left(\delta^{15} \mathrm{~N}\right)$ and carbon $\left(\delta^{13} \mathrm{C}\right)$ stable-isotope analysis was used to assess the trophic interactions and feeding habits of three notothenioid coastal fish (Champsocephalus esox, Patagonotothen tessellata and Patagonotothen cornucola) and one exotic salmon species (Oncorhynchus tschawytscha) with diverse life habits (benthic and benthopelagic) in the Francisco Coloane Coastal Marine Protected Area, southern Chile. The stomach contents of $C$. esox were mainly fish; those of $P$. cornucola and $O$. tschawytscha were crustacean decapods, Munida gregaria. A cluster analysis on isotope data and stable-isotope Bayesian ellipses detected two different predator groups, one with benthopelagic habits (C. esox and O. tshawytscha) and one with benthic habits ( $P$. cornucola and $P$. tessellata). These results were supported with similar isotopic trophic level of each group. We suggest that the exotic salmon 0 . tschawytscha is a generalist predator with a broad trophic niche that may compete with the native notothenioid $C$. esox, as both have equivalent trophic levels with substantial overlap. This preliminary study is the first on trophic relationships of a subtidal fish assemblage within a remote ecosystem of fjords and channels in Chile's southern Patagonia.
\end{abstract}

\section{KEYWORDS}

Notothenioidei; exotic salmonid; trophic level; feeding habits; Magellan region; sub-Antarctic

\section{ABBREVIATIONS}

ANOVA: analysis of variance analysis; CMPA: Coastal Marine Protected Area; HSD: Tukey's honest significant difference test; IRI: index of relative importance; SEAc: standard ellipse area corrected for sample size; TL: trophic level

\section{Introduction}

In the polar regions of the Southern Hemisphere, the notothenioids (Perciformes) occupy the intermediate trophic level in marine food webs (Kock et al. 2012). As both predators and prey, they play important ecological roles in the marine ecosystem, occupying most of the available trophic niches (Eastman 1993). As predators, they feed on benthic, zooplanktonic and nektonic organisms; as prey, the notothenioids are an important source of nutrition for top-level consumers, such as marine birds and mammals (Birt et al. 1987; Leopold et al. 1998; La Mesa et al. 2004). Despite their lack of a swim bladder, the notothenioids can prey on pelagic organisms in the water column because of a modified buoyancy-control mechanism involving reduced skeletal ossification and/or lipid deposits (Eastman 1993; Eastman \& Sidell 2002; Fernández et al. 2012). Thus, they exhibit diverse life habits benthic, benthopelagic, semi-pelagic and pelagic) which allow them to utilize food resources in a variety of habitats (Eastman 1993; Gröhsler 1994; Clarke \& Johnston 1996). Such a wide range of feeding habits may reduce dietary overlap and interspecific competition (Colwell \& Futuyma 1971; Odum 1971).
The notothenioid represented by the genera Champsocephalus, Cottoperca, Eleginops, Paranotothenia and Patagonotothen are the most important fish in terms of abundance and diversity of species in shallow subtidal areas $(<15 \mathrm{~m}$ depth $)$ of the fjord and channel ecosystems that make up the Francisco Coloane CMPA in Chile's southern Patagonia (Pequeño 2000, 2006; Sielfeld et al. 2006; Reyes \& Hüne 2012). This is the first (created in 2003) of three CMPAs along the Patagonian ecosystem of fjords and channels. Lying entirely in the Strait of Magellan, the CMPA supports high abundance of phyto-zooplankton (e.g., diatoms, copepods, decapods and euphausiids), providing resources to many top predators, such as seabirds and marine mammals (Haro et al. 2013). This ecosystem is potentially threatened by anthropogenic activities, such as the introduction of exotic salmonids during the 1970s to 1990s with the aim of establishing wild populations of chinook salmon (O. tschawytscha) in the western shores of Patagonia (Soto et al. 2007; Niklitschek et al. 2013). The relatively recent invasion of chinook salmon may constitute a major 
threat to near-shore biodiversity along the Beagle Channel (Fernández et al. 2010), increasing resource competition with native fish (e.g., Riccialdelli et al. 2017). However, there is scarce information on the invasive salmonid feeding behaviour and trophic interactions with the native, notothenioid coastal fish assemblage.

The purpose of this preliminary study is to determine the feeding habits and trophic interactions of three notothenioid coastal fishes and one exotic salmon species (O. tschawytscha) with benthic and benthopelagic habits in the Francisco Coloane CMPA through the combined approach of stomach content and stable-isotope $\left(\delta^{13} \mathrm{C}\right.$ and $\delta^{15} \mathrm{~N}$ ) analyses. This framework permits direct insight into the native fishes trophic positions and their trophic relationship with an invasive salmonid, assessing the threat of resource competition among invasive versus native fishes in a remote fjord and channel ecosystems of Chile's southern Patagonia. Two methods may be used to examine trophic relationships: stomach content analysis and stable-isotope ratios. Using both is the ideal approach to compensate for any inherent inaccuracy in each or either method. Stomach content analyses provide only a 'snapshot' of dietary habits, often encountering empty stomachs, and may show bias toward prey items with lower digestion rates (Hyslop 1980). The use of stableisotope $\left(\delta^{13} \mathrm{C}\right.$ and $\left.\delta^{15} \mathrm{~N}\right)$ signatures reflects biologically integrated nutrients in diet over a long time period (e.g. several months for muscle tissue; Peterson \& Fry 1987), but it does not provide direct evidence of an organism's prey items. The two methods in combination provide a more accurate picture of an organism's feeding habits than the use of a single method alone.

\section{Materials and methods}

The study site is Caleta Dighton $\left(53^{\circ} 49^{\prime} \mathrm{S}, 72^{\circ} 12^{\prime} \mathrm{W}\right)$, within the Barbara Channel, which connects with the
Strait of Magellan in the Francisco Coloane CMPA (Fig. 1). The samples were collected during April 2016. This pilot survey is framed within an ichthyology research initiative for a remote area of difficult access and where there is no empirical knowledge on diversity of native and introduced fishes, or on their ecological interactions. All fish were captured using a gill net (length $60 \mathrm{~m}$; height $3 \mathrm{~m}$; mesh size $2.5 \mathrm{~cm}$ ) from the bottom to the surface with 12 -h resting periods. All individuals caught were measured and weighed to obtain the size range $(\mathrm{cm})$ and total weight $(\mathrm{g})$. The entire digestive tract was removed and conserved in $80 \%$ ethanol for stomach content analysis. In the laboratory, stomach contents were identified to the lowest possible prey taxon, counted and weighed. The contribution of different prey items to the fishes' diet was determined by the IRI. The IRI is expressed as a percentage and calculated as: $\% \mathrm{IRI}=\% \mathrm{~F}(\% \mathrm{~N}+\% \mathrm{~W})$, where $\% \mathrm{~N}$ is the percentage by number, $\% \mathrm{~W}$ is the percentage by weight, and $\% \mathrm{~F}$ is the percentage of occurrence (Hyslop 1980; Cortés 1997).

A sample $\left( \pm 2 \mathrm{~cm}^{3}\right)$ of dorsal muscle tissue from each fish was frozen at $-80^{\circ} \mathrm{C}$ for stable-isotope analysis. In the laboratory, samples of dorsal muscle tissue were dried for $72 \mathrm{~h}$ at $60^{\circ} \mathrm{C}$ and subsequently homogenized. All samples underwent a process of lipid extraction with a solution of petroleum ether for $3 \mathrm{~h}$ in a Soxhlet extractor, as lipids are depleted in ${ }^{13} \mathrm{C}$ with respect to other macromolecules (e.g., proteins). It is assumed that the $\delta^{13} \mathrm{C}$ values will tend to be lower than in samples with a higher lipid content (DeNiro \& Epstein 1977). The isotopic composition of carbon and nitrogen was analysed in an isotope-ratio mass spectrometer (Thermo Delta Advantage), coupled with a Flash 2000 Elemental Analyzer by Thermo Scientific (Michener \& Lajtha 2007). The results were expressed in $\delta$ notation according to the following formula:

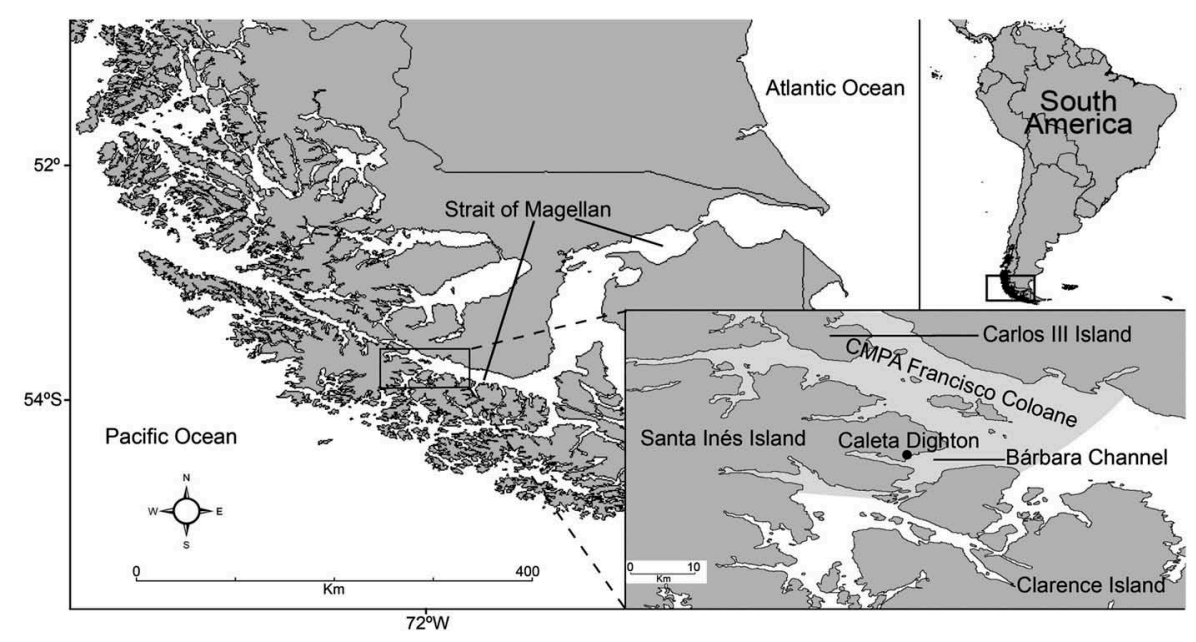

Figure 1. Study area in the Chilean southern Patagonia. Shown in the inset is the Francisco Coloane CMPA and study sites where Champsocephalus esox, Patagonotothen tessellata, P. cornucola and Oncorhynchus tschawytscha were collected (Table 1) in April 2016 from Caleta Dighton, connected to the Strait of Magellan by the Barbara Channel. 


$$
\delta X=\left[\left(R_{\text {sample }} / R_{\text {standard }}\right)-1\right] \times 1000,
$$

where $X$ is ${ }^{13} \mathrm{C}$ or ${ }^{15} \mathrm{~N}$, and $R$ is the corresponding ratio ${ }^{13} \mathrm{C} /{ }^{12} \mathrm{C}$ or ${ }^{15} \mathrm{~N} /{ }^{14} \mathrm{~N}$ for samples or standards (Unkovich et al. 2001). The Vienna Pee Dee Belemnite was used as a reference standard for comparison with $\delta^{15} \mathrm{C}$, and atmospheric nitrogen was used for comparison with $\delta^{15} \mathrm{~N}$. Data were subjected to the Shapiro-Wilk and Levene homoscedasticity tests. One-way ANOVA was used to compare isotope ratios between the different species, and pairwise comparisons between species were performed with HSD (Zar 2010). All statistical analyses were performed using the $\mathrm{R}$ software ( $\mathrm{R}$ Core Team 2013). The computer package Primer version 6 was used to generate hierarchical clustering based on applying Euclidean distances to isotope ratios (Clarke \& Gorley 2006). We used the isotopic signal of krill (Euphausia lucens) as primary consumer to estimate TL because their tissues integrate seasonal variability of particulate organic matter and phytoplankton (Cabana \& Rasmussen 1996; Van der Zanden et al. 1997). Krill was collected using a $250 \mu \mathrm{m}$ net, during March of 2012 and 2016 in Caleta Dighton (Halo et al. 2016). We estimated TL using the following equation (Cabana \& Rasmussen 1996; Van der Zanden et al. 1997):

$$
\mathrm{TL}=2+\left(\delta^{15} \mathrm{~N}_{\text {consumer }}-\delta^{15} \mathrm{~N}_{\text {primaryconsumer }}\right) / 3.4,
$$

where 2 is the TL of primary consumer, $\delta^{15} \mathrm{~N}_{\text {consumer }}$ is the $\delta^{15} \mathrm{~N}$ of the species considered, and 3.4 is the $\delta^{15} \mathrm{~N}$ enrichment TL (Post 2002). To estimate isotopic niche, we calculated the SEAc and dietary niche overlap with stable-isotope Bayesian ellipses for $\mathrm{R}$ using the SIAR package in $\mathrm{R}$ (Jackson et al. 2011).

\section{Results and discussion}

We collected 12 specimens of Champsocephalus esox, three Paranotothenia tessellata, 10 Patagonotothen cornucola and three Oncorhynchus tschawytscha (Table 1). Seven of the 28 stomachs examined were empty. The majority of the empty stomachs were of the icefish (C. esox, 50\%). The diet of C. esox consisted mainly of fish prey items (Patagonotothen sp.; IRI $=40.1 \%$; Supplementary Table S1). The main diet of $P$. tessellata was the gammarid crustacean Austroregia sp. (IRI $=34.5 \%)$ and the decapod
Munida gregaria (IRI = 19.8\%). The diet of $P$. cornucola consisted of the crustacean decapod M. gregaria $($ IRI $=46.6 \%)$ and unidentified fish preys (IRI $=18.1 \%)$. The salmonid O. tschawytscha preyed mainly on $M$. gregaria (IRI $=52.2 \%$; Supplementary Table S1).

Except for C. esox, all the species examined fed on M. gregaria. This crustacean decapod was the main prey as a percentage by weight for $O$. tschawytscha in Aysen fjord $\left(45^{\circ} 16^{\prime} \mathrm{S}, 73^{\circ} 00^{\prime} \mathrm{W}\right.$; Niklitschek \& Toledo 2011). However, in terms of relative importance, the notothenioid was the main prey item of $O$. tschawytscha in Aysen fjord, with a high percentage of occurrence in the salmonid stomachs (Niklitschek \& Toledo 2011). A plausible explanation for the absence of notothenioid in the diet of $O$. tschawytscha could be the low number of stomachs analysed in this pilot study. Munida gregaria constituted the bulk of $P$. cornucola's diet, but in prior studies the crustacean isopod Exosphaeroma gigas and gammarid crustaceans were their main prey items in the intertidal zone of the Patagonian fjords and channels (Hüne \& Vega 2016). Our results in C. esox are in agreement with its reportedly piscivorous diet (Moreno \& Jara 1984), feeding primarily on Patagonotothen species in mid-water.

Patagonotothen tessellata had the highest isotopic mean values for $\delta^{13} \mathrm{C}$, and $O$. tshawytscha had the lowest (Table 1). Champsocephalus esox had the highest isotopic mean values for $\delta^{15} \mathrm{~N}$, and both $P$. cornucola and $P$. tessellata had the lowest $\delta^{15} \mathrm{~N}$ (Table 1). There were highly significant differences between mean isotopic values in the four species (one-way ANOVA: $\delta^{13} \mathrm{C}$, $\left.F=5.74, p=0.00 ; \delta^{15} \mathrm{~N}, F=30.88, p=0.00\right)$. We found statistically significant differences in mean isotopic values between $P$. tessellata and C. esox (HSD: $\delta^{13} \mathrm{C}, p=0.01$; $\left.\delta^{15} \mathrm{~N}, p=0.00\right)$ and between $P$. tessellata and $O$. tshawytscha (HSD: $\delta^{13} \mathrm{C}, p=0.01 ; \delta^{15} \mathrm{~N}, p=0.02$ ). Similarly, $P$. cornucola showed significant differences in $\delta^{15} \mathrm{~N}$ with C. esox and O. tshawytscha (HSD, both $p=0.00$ ). Our results agree with the cluster analysis based on isotope data, which detected two different groups, one with benthopelagic fish habits (C. esox and O. tshawytscha) and one with benthic fish habits ( $P$. cornucola and $P$. tessellata; Fig. 2). Marked differences between consumer groups with dissimilar life styles would be expected, implying that available resources are distributed among consumers that occupy different trophic levels.

Table 1. Fishes sampled from Caleta Dighton, in the Barbara Channel, Francisco Coloane CMPA in Chile's southern Patagonia (Fig. 1) for stomach content and stable-isotope analysis: total number of fishes sampled per species, size range, mean $\delta^{15} \mathrm{~N}-$

\begin{tabular}{|c|c|c|c|c|c|c|c|}
\hline Species & Habitat & $n$ & Size range $(\mathrm{cm})$ & $\delta^{15} \mathrm{~N}$ & $\delta^{13} \mathrm{C}$ & TL & SEAC \\
\hline C. esox (pike icefish) & Benthopelagic & 12 & $28-34$ & $15.3 \pm 0.3$ & $-16.0 \pm 0.4$ & 3.02 & 0.38 \\
\hline P. tessellata (rockcod) & Benthic & 3 & $18.5-20$ & $13.9 \pm 0.3$ & $-14.7 \pm 0.5$ & 2.61 & 0.82 \\
\hline P. cornucola (rockcod) & Benthic & 10 & $19-26.5$ & $13.9 \pm 0.4$ & $-15.4 \pm 0.7$ & 2.61 & 0.79 \\
\hline O. tshawytscha (chinook salmon) & Benthopelagic & 3 & $31.5-62$ & $14.9 \pm 0.4$ & $-16.2 \pm 0.6$ & 2.91 & 0.98 \\
\hline
\end{tabular}
$\delta^{13} \mathrm{C}$, TL and SEAC. 
Euphausia lucens $(n=6)$ showed a mean $\delta^{15} \mathrm{~N}$ value of $11.83 \pm 0.6 \%$ in the geographic area of this study. Using this as the reference primary consumer to estimate TL, we found that C. esox occupied the highest TL (3.02; range 2.85-3.23) followed by $O$. tshawytscha (2.91; range 2.81-3.05), whereas $P$. cornucola and $P$. tessellata showed lower TLs with 2.61 (range $=2.46-2.86)$ and $2.61(2.54-$ 2.71) than the benthopelagic fish (Fig. 2). However, in terms of the range of displacement of the species analysed, $O$. tshawytscha, as an anadromous species, inhabits the ocean and freshwater environments at different stages in its life cycle and performs long migrations, increasing its habitat range (Soto et al. 2007). Oncorhynchus tshawytscha could have a greater foraging range than the other species examined and be able to consume similar prey but in areas with different basal isotopic signal. Therefore, the foraging distance of $O$. tshawytscha could have influenced the $\delta^{15} \mathrm{~N}$ signal estimated in this study and the estimated high trophic level. According to Wainright et al. (1996) and Michener \& Kaufman (2007), it is difficult to determine whether the isotopic composition of mobile organisms reflects local feeding habits or the diet from other zones with different isotopic composition. Oncorhynchus tshawytscha and $P$. tessellata occupy lower TL in the fjords and channels ecosystem of the Francisco Coloane CMPA than they do along the Atlantic coast of Argentina (O. tshawytscha 4.87 TL; Ciancio et al. 2008) and Bahia Lapataia (54 $51^{\circ} \mathrm{S}$, $\left.68^{\circ} 32^{\prime} \mathrm{W}\right)$ in the Beagle Channel, south-western Argentina (P. tessellata 4.5 TL; Riccialdelli et al. 2017). The different TLs of the same species in different geographic areas may relate to the variation in the baseline isotopic signal in each geographic area (Fry 2008; Graham et al. 2010).

In agreement with the cluster analysis, the isotopic niche area $\left(\%^{2}\right)$ of C. esox, P. tessellata, P. cornucola and O. tschawytscha, shown by the SEAc plot (Fig. 3), differentiates between the benthopelagic fish habits
(C. esox and O. tshawytscha) and the benthic fish habits ( $P$. cornucola and P. tessellata; Fig. 3). The SEAc overlap between C. esox and O. tshawytscha was 0.27 , whereas the overlap between $P$. cornucola and $P$. tessellata was 0.21 . The SEAc ranged from $0.98 \%{ }^{2}$ (O. tschawytscha) to $0.38 \%{ }^{2}$ (C. esox). The isotopic niche area of $O$. tschawytscha is relatively large in comparison with the small niche area of $C$. esox, suggesting the use of a wide range of resources (e.g., habitat and diet) by the invasive salmonid versus a low diversity of resources used by the native nothotenioid (Table 1, Fig. 3). However, this preliminary result should be further validated with the larger sample size of $O$. tschawytscha.

Segregation of microhabitats is an important factor for reducing the effects of competition for resources (Ross 1986; Grossman et al. 1987; Rinóon \& Lobón-Cerviá 1993). In our study, trophic differences could relate to the habitat use by fish species with diverse lifestyles (e.g., benthic and benthopelagic). Another factor that might reduce the effects of trophic competition relates to differences in the diel activity patterns of fish (Hansen \& Closs 2005; David et al. 2007). The nocturnal feeding activity, for instance, has been observed for $P$. tessellata in the subtidal waters of Patagonian channels (Salas-Berrios et al. 2013; Hüne \& Vega 2015). In contrast, O. tschawytscha are diurnal feeders (Schabetsberger et al. 2003). Along the coast of Tierra del Fuego Island, the southernmost tip of Patagonia, the chinook salmon may compete for food resources with the Magellanic penguin (Spheniscus magellanicus) and with Commerson's dolphin (Cephalorhynchus commersonii) because these predators occupy similar TLs and feed on similar fish, cephalopods and crustaceans (Ciancio et al. 2008; Niklitschek \& Toledo 2011; Riccialdelli et al. 2013; Scioscia et al. 2014).

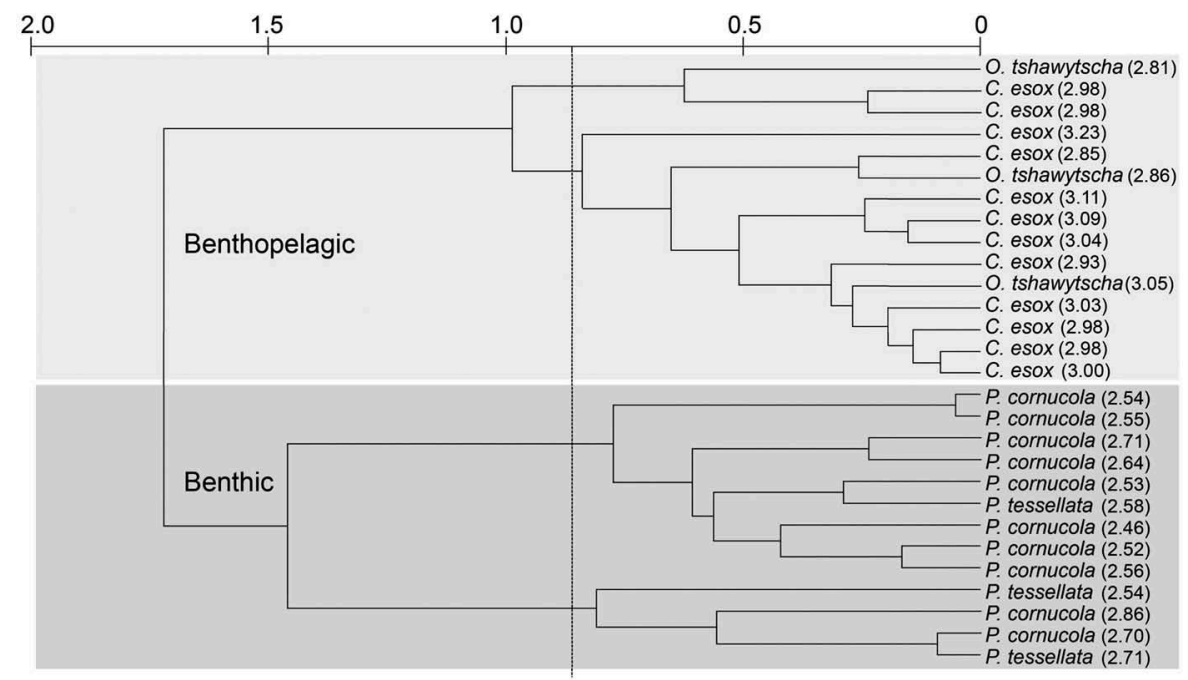

Figure 2. Dendrogram based on $\delta^{13} \mathrm{C}$ and $\delta^{15} \mathrm{~N}$ values from a subtidal fish assemblage from Caleta Dighton (Barbara Channel; Fig.1) in the Francisco Coloane CMPA, Chile's southern Patagonia. Numbers in parentheses are the estimated TL. 


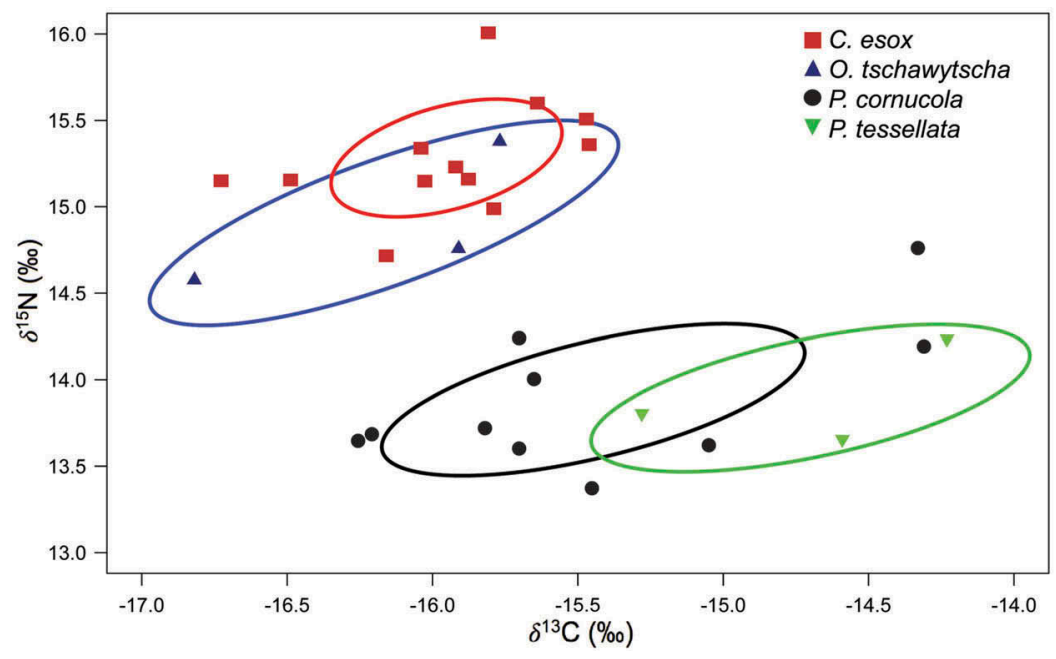

Figure 3. Standard ellipse area (solid lines) depicting trophic niche breadth and overlap based on SEAc analysis for Champsocephalus esox, Patagonotothen tessellata, P. cornucola and Oncorhynchus tschawytscha sampled from Caleta Dighton (Barbara Channel) in the Francisco Coloane CMPA, Chile's southern Patagonia (Fig.1).

Our results suggest that $O$. tschawytscha are generalist predators with a broad isotopic niche, possibly competing with the icefish (C. esox), as both have equivalent TLs. Regarding the broad isotopic niche of $O$. tschawytscha, our results on stomach content analyses indicated that $O$. tschawytscha feed mainly on the decapod $M$. gregaria, but the chinook salmon could feed on several prey items (Niklitschek \& Toledo 2011). In addition, the foraging ranges of chinook salmon could encompass a wide geographical area, which would influence its broad isotopic niche. Continued sampling and analyses of more specimens will further our understanding on the trophic relationships and the ecological consequences of resource competition among exotic salmonids in the Francisco Coloane CMPA and its native, subtidal fish assemblages.

\section{Acknowledgements}

We thank the tourism company Expedición FitzRoy for logistical support during fieldwork, especially Juan José Salas and the crew of the M/N Forrest. Also, we thanks Dr Francisco Elgueta for his on-site assistance with fish surgery and throughout the fieldwork activities. Finally, we thank José Saavedra for his help with the taxonomic identification of invertebrate taxa.

\section{Disclosure statement}

No potential conflict of interest was reported by the authors.

\section{Funding}

This study was funded by Chile's National Commission for Scientific and Technological Research (CONICYT) Regional Program (Programa Regional) and Linking Science and the Enterprise Project (Proyecto de Vinculación Ciencia-Empresa), project number CONICYT-VCE 5 N000003.

\section{References}

Birt V., Birt T., Goulet D., Cairns D. \& Montevecchi W. 1987. Ashmole's halo: direct evidence for prey depletion by a seabird. Marine Ecology Progress Series 40, 205-208.

Cabana G. \& Rasmussen J.B. 1996. Comparison of aquatic food chains using nitrogen isotopes. Proceedings of the National Academy of Sciences 93, 10844-10847.

Ciancio J.E., Pascual M.A., Botto F., Frere E. \& Iribarne O. 2008. Trophic relationships of exotic anadromous salmonids in the southern Patagonian Shelf as inferred from stable isotopes. Limnology and Oceanography 53, 788-798.

Clarke A. \& Johnston I.A. 1996. Evolution and adaptive radiation of Antarctic fishes. Trends in Ecology \& Evolution 11, 212-218.

Clarke K.R. \& Gorley R.N. 2006. Primer v6. User manual/ tutorial. Plymouth: Primer-E, Plymouth Marine Laboratory, Natural Environmental Research Council.

Colwell R.K. \& Futuyma D.J. 1971. On the measurement of niche breadth and overlap. Ecology 52, 567-576.

Cortés E. 1997. A critical review of methods of studying fish feeding based on analysis of stomach contents: application to elasmobranch fishes. Canadian Journal of Fisheries and Aquatic Sciences 54, 726-738.

David B., Closs G., Crow S. \& Hansen E. 2007. Is diel activity determined by social rank in a drift-feeding stream fish dominance hierarchy? Animal Behaviour 74, 259-263.

DeNiro M.J. \& Epstein S. 1977. Mechanism of carbon isotope fractionation associated with lipid synthesis. Science 197, 261-263.

Eastman J.T. 1993. Antarctic fish biology: evolution in a unique environment. San Diego, CA: Academic Press.

Eastman J.T. \& Sidell B.D. 2002. Measurements of buoyancy for some Antarctic notothenioid fishes from the South Shetland Islands. Polar Biology 25, 753-760.

Fernández D.A., Ciancio J., Ceballos S.G., Rosi C.R. \& Pascual M.A. 2010. Chinook salmon (Oncorhynchus tshawytscha, Walbaum 1792) in the Beagle Channel, Tierra del Fuego: the onset of an invasion. Biological Invasions 12, 2991-2997.

Fernández D.A., Santiago C.G., Malanga G., Boy C.C. \& Vanella F.A. 2012. Buoyancy of sub-Antarctic notothenioids including the sister lineage of all other notothenioids (Bovichtidae). Polar Biology 35, 99-106. 
Fry B. 2008. Stable isotope ecology. 3rd edn. New York: Springer Science Business Media.

Graham B.S., Koch P.L., Newsome S.D., McMahon K.W. \& Aurioles D. 2010. Using isoscapes to trace the movements and foraging behavior of top predators in oceanic ecosystems. In J.B. West et al. (eds.): Isoscapes: understanding movement, pattern, and process on Earth through isotope mapping. Pp. 299-318. Dordrecht: Springer.

Gröhsler T. 1994. Feeding habits as indicators of ecological niches: investigations of Antarctic fish conducted near Elephant Island in late autumn/winter 1986. Archive of Fishery and Marine Research 42, 17-34.

Grossman G., de Sostoa A., Freeman M. \& Lobón-Cerviá J. 1987. Microhabitat use in a Mediterranean riverine fish assemblage. Fishes of the Upper Matarraña. Oecologia 73, 501-512.

Hansen E. \& Closs G. 2005. Diel activity and home range size in relation to food supply in a drift-feeding stream fish. Behavioral Ecology 16, 640-648.

Haro D., Aguayo-Lobo A. \& Acevedo J. 2013. Características oceanográficas y biológicas de las comunidades del plancton y necton del Área Marina Costera Protegida Francisco Coloane: una revisión. (Oceanographic and biological characteristics of the plankton and nekton communities in the Coastal Marine Protected Area Francisco Coloane: a review.) Anales Instituto Patagonia 41, 77-90.

Haro D., Riccialdelli L., Acevedo J., Aguayo-Lobo A. \& Montiel A. 2016. Trophic ecology of humpback whales (Megaptera novaeangliae) in the Magellan Strait as indicated by carbon and nitrogen stable isotopes. Journal of Aquatic Mammals 42, 233-243.

Hüne M. \& Vega R. 2015. Spatial variation in the diet of Patagonotothen tessellata (Pisces, Nototheniidae) from the fjords and channels of southern Chilean Patagonia. Polar Biology 38, 1613-1622.

Hüne M. \& Vega R. 2016. Feeding habits in two sympatric species of Notothenioidei, Patagonotothen cornucola and Harpagifer bispinis, in the Chilean Patagonian channels and fjords. Polar Biology 39, 2253-2262.

Hyslop J. 1980. Stomach contents analysis. A review of methods and their application. Journal of Fish Biology 17, 411-429.

Jackson A.L., Inger R., Parnell A.C. \& Bearhop S. 2011. Comparing isotopic niche widths among and within communities: SIBER-stable isotope Bayesian ellipses in R. The Journal of Animal Ecology 80, 595-602.

Kock K.-H., Barrera-Oro E., Belchier M., Collins M.A., Duhamel G., Hanchet S., Pshenichnov L., Welsford D. \& Williams R. 2012. The role of fish as predators of krill (Euphausia superba) and other pelagic resources in the southern ocean. CCAMLR Science 19, 115-169.

La Mesa M., Eastman J.T. \& Vacchi M. 2004. The role of notothenioid fish in the food web of the Ross Sea shelf waters: a review. Polar Biology 27, 321-338.

Leopold M., van Damme C. \& van der Veer H. 1998. Diet of cormorants and the impact of cormorant predation on juvenile flatfish in the Dutch Wadden Sea. Journal of Sea Research 40, 93-107.

Michener R. \& Lajtha K. 2007. Stable isotopes in ecology and environmental science. Boston, MA: Blackwell Publishers.

Michener R.H. \& Kaufman L. 2007. Stable isotope ratios as tracers in marine food webs: an update. In R.H. Michener \& K. Lajtha (eds.): Stable isotopes in ecology and environmental science. Pp. 238-282. Boston, MA: Blackwell Publishing.
Moreno C. \& Jara F. 1984. Ecological studies on fish fauna associated with Macrocystis pyrifera belts in the south of Fueguian Islands, Chile. Marine Ecology Progress Series 15, 99-107.

Niklitschek E.J., Soto D., Lafon A., Molinet C. \& Toledo P. 2013. Southward expansion of the Chilean salmon industry in the Patagonian fjords: main environmental challenges. Reviews in Aquaculture 5, 172-195.

Niklitschek E.J. \& Toledo P. 2011. Evaluación cuantitativa del estado trófico de salmónidos de vida libre en el Fiordo Aysén, XI Región. Informe Final FIP 2008-30. (Quantitative evaluation of the trophic status of free-living salmonids in the Aysén Fjord, Region XI. Final Report FIP 2008-30.) Coyhaique: Universidad Austral de Chile.

Odum E.P. 1971. Fundamentals of ecology. Philadelphia, PA: W.B Saunders Company.

Pequeño G. 2000. Peces del crucero CIMAR-Fiordo 3, a los canales del sur de Magallanes (ca. 55 S), Chile. (Fishes of the CIMAR-Fiordo 3 cruise to the channels of the south Magellan region [ca. 55 S], Chile.) Ciencia $y$ Tecnología del Mar 23, 83-94.

Pequeño G. 2006. Peces litorales de los canales y fiordos australes. (Coastal fishes of southern channels and fjords.) In N. Silva \& S. Palma (eds.): Avances en el conocimiento oceanográfico de las aguas interiores Chilenas, Puerto Montt a cabo de Hornos. (Advances in oceanographic knowledge of Chilean inland waters, Puerto Montt to Cape Horn.) Pp. 129-132. Valparaíso: National Oceanographic Committee (Comité Oceanográfico Nacional).

Peterson B.J. \& Fry B. 1987. Stable isotopes in ecosystem studies. Annual Review of Ecology and Systematics 18, 293-320.

Post D.M. 2002. Using stable isotopes to estimate trophic position: models, methods, and assumptions. Ecology 83, 703-718.

R Core Team. 2013. R: a language and environment for statistical computing. Vienna: $\mathrm{R}$ Foundation for Statistical Computing.

Reyes P. \& Hüne M. 2012. Peces del Sur de Chile. (Fishes of southern Chile.) Santiago de Chile: Ocho Libros Ediciones.

Riccialdelli L., Newsome S.D., Dellabianca N.A., Bastida R., Fogel M.L. \& Goodall R.N.P. 2013. Ontogenetic diet shift in Commerson's dolphin (Cephalorhnychus commersonii commersonii) off Tierra del Fuego. Polar Biology 36, 617-627.

Riccialdelli L., Newsome S.D., Fogel M.L. \& Fernández D.A. 2017. Trophic interactions and food web structure of a Subantarctic marine food web in the Beagle Channel: Bahía Lapataia, Argentina. Polar Biology 40, 807-821.

Rinóon P. \& Lobón-Cerviá J. 1993. Microhabitat use by stream-resident brown trout: bioenergetic consequences. Transactions of the American Fisheries Society 122, 575-587.

Ross S. 1986. Resource partitioning in fish assemblages: a review of field studies. Copeia 1986, 352-388.

Salas-Berrios F., Valdés-Aguilera J., Landaeta M.F., Bustos C. A., Pérez-Vargas A. \& Balbontín F. 2013. Feeding habits and diet overlap of marine fish larvae from the periAntarctic Magellan region. Polar Biology 36, 1401-1414.

Schabetsberger R., Morgan C.A., Brodeur R.D., Potts C.L., Peterson W.T. \& Emmett R.L. 2003. Prey selectivity and diel feeding chronology of juvenile chinook (Oncorhynchus tshawytscha) and coho (O. kisutch) salmon in the Columbia River plume. Fisheries Oceanography 12, 523-540. 
Scioscia G., Raya Rey A., Saenz Samaniego R.A., Florentín O. \& Schiavini A. 2014. Intra- and interannual variation in the diet of the Magellanic penguin (Spheniscus magellanicus) at Martillo Island, Beagle Channel. Polar Biology 37, 1421-1433.

Sielfeld W., Guzman G. \& Amado N. 2006. Distribución de peces del litoral rocoso de los canales patagónicos occidentales $\left(48^{\circ} 37^{\prime} \mathrm{S}-53^{\circ} 34^{\prime} \mathrm{S}\right)$. (Distribution of rocky shore fishes of the west patagonian channels [48 $37^{\prime} S$ - 5334'S].) Anales del Instituto de la Patagonia 34, 21-32.

Soto D., Arismendi I., Di Prinzio C. \& Jara F. 2007. Establishment of chinook salmon (Oncorhynchus tshawytscha) in Pacific basins of southern South America and its potential ecosystem implications. Revista Chilena de Historia Natural 80, 81-98.
Unkovich M., Pate J., McNeill A. \& Gibbs D.J. (eds.) 2001. Stable isotope techniques in the study of biological processes and functioning of ecosystems. Dordrecht: Kluwer Academic Publishers.

Van der Zanden M.J., Cabana G. \& Rasmussen J.B. 1997. Comparing trophic position of freshwater fish calculated using stable nitrogen isotope ratios $\left(\delta^{15} \mathrm{~N}\right)$ and literature dietary data. Canadian Journal of Fisheries and Aquatic Sciences 54, 1142-1158.

Wainright S.C., Fuller C., Michener R. \& Richards R.A. 1996. Spatial variation of growth rate and trophic position of juvenile striped bass (Morone saxitalis) in the Delaware River. Canadian Journal of Fisheries and Aquatic Sciences 53, 685-692.

Zar J.H. 2010. Biostatistical analysis. Upper Saddle River, NJ: Prentice Hall. 